\title{
EFEKTIVITAS PENYULUHAN KESEHATAN DALAM MENINGKATKAN PENGETAHUAN KADER POSYANDU TENTANG PENCEGAHAN PNEUMONIA PADA BALITA
}

\section{(Effectiveness of health counseling in improving knowledge of posyandu volunteers about prevention of pneumonia in toddler)}

\author{
Rapitos Sidiq ${ }^{{ }^{*}}$ \\ ${ }^{1}$ Jurusan Keperawatan Politeknik Kesehatan Kemenkes Aceh. E-mail: rapitossidiq@ poltekkesaceh.ac.id \\ Received: $12 / 3 / 2018$ \\ Accepted: $15 / 4 / 2018$ \\ Published online: $3 / 5 / 2018$
}

\begin{abstract}
ABSTRAK
Kejadian Pneumonia pada balita masih menjadi permasalahan di dunia termasuk Indonesia. Banyak faktor yang melatarbelakangi kejadian penyakit ini, baik faktor lingkungan maupun perilaku manusia. Salah satu uapaya yang dilakukan untuk pencegahan penyakit ini adalah dengan peningkatan peran kader posyandu untuk kegiatan promotif dan preventif termasuk mempromosikan perilaku pencarian pertolongan kesehatan dan perawatan balita di rumah, sehingga setiap kader dituntut mengetahui tentang pencegahan pneumonia tersebut. Secara uтu penelitian ini ingin melihat efektivitas penyuluhan kesehatan dalam meningkatkan pengetahuan kader posyandu tentang pencegahan penyakit pneumonia pada balita di wilayah kerja Puskesmas Darul Kamal Tahun 2017. Penelitian menggunakan metode quasi eksperimental dengan rancangan one group pretest-postest design. Jumlah sampel penelitian 30 orang. Uji statistic yang digunakan paired t-tes tingkat kemaknaan ( $\alpha$ ) 0,05 (5\%). Penelitian ini menghasilkan nilai pengetahuan kader sebelum dan sesudah intervensi adalah 27,17:29,00 dengan p-value 0,003 (<0,05). Penyuluhan kesehatan efektif dalam meningkatkan pengetahuan kader posyandu tentang pencegahan penyakit pneumonia
\end{abstract}

Kata kunci : Penyuluhan kesehatan, pengetahuan, kader posyandu, pneumonia, balita

\begin{abstract}
The incidence of pneumonia in toddler is still a problem in the world including Indonesia. Many factors caused the incidence of this disease, both environmental factors and human behavior. One of the efforts undertaken for the prevention of this disease is by increasing the role of posyandu cadres for promotive and preventive activities including promoting health seeking behavior and home toddler care, so that each cadre is required to know about the prevention of pneumonia. In general, this research would like to see the effectiveness of health counseling in increasing the knowledge of posyandu cadres on prevention of pneumonia disease in under-five children in the work area of Puskesmas
\end{abstract}

Darul Kamal 2017. The study used quasi experimental method with one group pretest-posttest design. The sample size is 30 people. Test statistic used paired t-test significance level $(\alpha) 0.05$ (5\%). This study yields cadre knowledge value before and after intervention is 27,17: 29,00 with p-value 0,003 (<0,05). Health counseling is effective in increasing knowledge of posyandu Volunteers about prevention of pneumonia disease.

Keywords: Health counseling, knowledge, cadres, pneumonia, toddler

\section{PENDAHULUAN}

Pneumonia merupakan salah suatu masalah kesehatan global yang sangat penting pada anak balita khususnya pada negera-negara berkembang. Penyakit ini disebabkan oleh virus pneumococcus yang sebagian besar menyerang usia diatas 65 tahun dan anak -anak yang mengalami penurunan daya tahan tubuh. ${ }^{1}$ Saat ini pneumonia merupakan salah satu kasus penyebab kematian pada anak terbesar terutama pada periode baru lahir. ${ }^{2}$ Sehingga WHO berkerjasama dengan lembaga kesehatan anak dunia UNICEF membentuk sebuah manajemen terpadu balita sakit atau The Integrated Manaagement of Childhood Illness (IMCI) atau di Indonesia kegiatan ini lebih dikenal dengan Manajemen terpadu balita sakit (MTBS). Tujuan dari kegiatan tersebut adalah untuk menurunkan angka kematian dan kesakitan anak akibat penyakit termasuk Pneumonia. ${ }^{3}$ Angka kematian balita akibat pneumonia mencapai 30\% pada tahun 1993. Sehinggatujuan pembangunan melinium atau The Millennium Development Goal ke-4(MDG

${ }^{*}$ Penulis untuk korespondensi: rapitossidiq@poltekkesaceh.ac.id 
4)adalah menargetkan penurunan angka kesakitan pneumnia $2 / 3$ dari jumlah total dari tahun 1990 sampai dengan 2015. ${ }^{4}$ Dirjen pemberantasan penyakit menular dan penyehatan lingkungan (P2MPL) Kemetrian Kesehatan RI memperkirakan kematian akibat pneumonia sebagai penyebab utama ISPA di Indonesia pada akhir tahun 2000 sebanyak lima kasus di antara 1.000 bayi dan balita. Berarti akibat pneumonia sebanyak 150.000 bayi dan balita meninggal tiap tahun atau 12.500 korban perbulan atau 416 kasus sehari atau 17 anak perjam atau seorang bayi dan balita tiap lima menit. Sedangkan berdasarkan Program Pembangunan Nasioanal (Propenas) bidang kesehatan, menambah angka kematian 5 per 1000 pada 2000 akan diturunkan menjadi 3/1000 pada akhir 2005. ${ }^{5}$

Provinsi Aceh penyakit ISPA pneumonia merupakan penyakit urutan ke-8 dari 25 penyakit terbesar yang ditemukan di Puskesmas dengan jumlah 1.112 kasus. Sedangkan besarnya kasus ISPA pneumonia pada penderita rawat jalan di Aceh mencapai 434 kasus $29,03 \% .^{6}$

Kecamatan Darul Kamal merupakan salah satu wilayah yang ada di Aceh Besar yang terdiri dari dari empat belas desa yaitu, Biluy, Blangkiree, Empetring, Lhang, Lamsod, Lambatee, Lambaro Biluy, Lambleut, Lamkunyet, Lamtadok, Manedeah, Neusok, Turam, Teubaluy. Kasus Pneumonia di Kecamatan Darul Kamal selalu ada dari tahun ke tahun meskipun telah dilakukan upaya pencegahan. Dari data penyakit pneumonia yang di peroleh dari Puskesmas Darul Kamal Aceh Besar pada tanggal 22 Januari 2015, diketahui bahwa pada tahun 2012 terdapat jumlah balita sebanyak 47 dengan kasus 11,80\% di desa Lamkunyet, pada tahun 2013 terdapat jumlah balita sebanyak 40 dengan kasus 8,38\% desa Lambatee, dan tahun 2014 kasus pneumonia semakin meningkat mencapai $13,39 \%$ dari 77 orang balita di desa terebut. ${ }^{7}$

Wilayah kerja Puskemas Darul Kamal ini terdiri dari gampong-gampong yang terletak di dataran yang luas, yang terdiri dari daerah persawahan, dan kebun kelapa sehingga banyak dari warga yang bermata pencaharian sebagai petani yang memiliki ternak seperti sapi, kerbau dan kambing dan seperti warga desa/gampong pada umumnya lokasi kandang ternak tersebut letaknya tidak jauh dari rumah, seperti yaitu dibelakang, samping rumah bahkan ada yang menyatu dengan dinding rumah.

Kondisi kadang ternak yang berdekatan dengan rumah tersebut akan mempengaruhi kebersihan lingkungan rumah, terutama kondisi fisik lingkungan rumah menjadi tidak sehat terutama pada musim hujan. Dinding rumah masyarat sebagian besar terbuat dari kayu atau batu bata yang belum diplaster. Masyarakat Gampong ini masih menggunakan kayu dan sabut kelapa untuk memasak. Suatu hal yang menarik ialah ketika musim panen selesai masyarakat selalu membakar jerami, sehingga suasana Gampong penuh dengan kabut asap. Penelitian membuktikan bahwa asap dari kayu bakar di dapur sama efeknya dengan asap yang ada di lingkungan rumah terhadap kesehatan perempuan dan anak-anak, terutama balita. ${ }^{8,9}$ Kejadian pneumonia pada balita sangat dipengaruhi oleh banyak faktor, seperti status sosial ekonomi, perilaku, kondisi fisik rumah, sumber air minum, kondisi ventilasi dapur, sistem pembuangan air limbah rumah tinggal. ${ }^{3}$ WHO mengidentifikasi bahwa faktor lingkungan yang dapat meningkatkan kerentanan anak untuk pneumonia adalah polusi udara dalam ruangan yang disebabkan oleh memasak dan pemanasan dengan bahan bakar seperti kayu atau kotoran, tinggal di rumah yang penuh sesak serta orangtua yang merokok. ${ }^{10}$ Penelitian Sidiq et al, menemukan bahwa bahwa faktor kondisi sanitasi rumah secara fisik berpengaruh terhadap kecendrungan balita menderita penyakit pneumonia dengan nilai $\mathrm{p}$ $0,010<0,05$, dengan nilai OR tertinggi 6,431 dan CI 95\% = $1.559-26.532 .^{11}$

Sehubungan dengan hal tersebut salah satu upaya pemerintah dalam menurunkan angka kematian dan kesakitan anak akibat penyakit Pneumonia tertuang dalam Permenkes RI Nomor 70 tahun 2013 pasal 5 ayat (1) dijelaskan bahwa pelayanan MTBS-berbasis masyarakat atau MTBS-M dilakukan oleh kader setempat yang telah mendapatkan pelatihan sebagai pelaksana. Pasal 7 menjelaskan juga bahwa kader berfokus pada kegiatan promotif dan preventif termasuk mempromosikan 
perilaku pencarian pertolongan kesehatan dan perawatan balita di rumah. Manajemen pneumonia dalam tatanan komunitas merupakan strategi penting untuk meningkatkan akses ke kualitas perawatan pneumonia, salah satunya adalah melatih dan menyebarkan community health worker untuk mengkaji dan merawat anak dengan pneumonia. $^{12}$

Penelitian ini ingin melihat efektivitas penyuluhan kesehatan dalam meningkatkan pengetahuan kader posyandu tentang pencegahan penyakit pneumonia pada balita di wilayah kerja Puskesmas Darul Kamal Tahun 2017.

\section{DESAIN PENELITIAN}

Metode yang digunakan dalam penelitian ini adalah quasi eksperimental dengan menggunakan rancangan one group pretestpostest design. Sampel penelitian adalah semua kader posyandu yang mengikuti kegiatan penyuluhan dengan jumlah 30 orang. Penelitian ini diawali dengan pemberian kuesioner (pretest), setelah itu peneliti mengadakan penyuluhan. Untuk mengetahui keefektivitasan penyuluhan, peneliti melakukan pemberian kuesioner yang sama (posttest). Semua kegiatan ini dilakukan pada tangal 21 Agustus 2017 bertempat di Puskesmas Darul Kamal Acxeh Besar. Tahapan Pengolahan data; editing, coding, transfering dan tabulating. Analisa data univariat dalam bentuk tabel distribusi frekuensi serta uji statistik paired t-tes tingkat kemaknaan $(\alpha) 0,05$

\section{HASIL DAN PEMBAHASAN}

\section{Karakteristik Subjek}

Data karakteristik responden berdasarkan umur, pendidikan, pekerjaan dan lama menjadi kader posyandu, secara rinci dapat dilihat pada tabel 1. Berdasarkan tabel. 1 didapatkan bahwa dari karakteristik umur, sebagian besar responden berusia 36-35 tahun yaitu $43,3 \%$, dari segi pendidikan sebagian besar berada pada katagori menengah yaitu
$53,4 \%$, sebagian besar tidak bekerja yaitu 93,3\% serta lama menjadi kader sebagian besar berkisar antara 2-5 tahun yaitu $60 \%$.

Tabel 1. Karakteristik responden

\begin{tabular}{lcc}
\hline \multicolumn{1}{c}{ Karakteristik } & $\mathbf{n}$ & $\mathbf{\%}$ \\
\hline Umur & & \\
26-35 Tahun & 11 & 36,7 \\
36-45 Tahun & 13 & 43,3 \\
46-55 Tahun & 2 & 6,7 \\
Pendidikan & & \\
$\quad$ Dasar & 10 & 33,3 \\
$\quad$ Menengah & 16 & 53,4 \\
$\quad$ Tinggi & 4 & 13,3 \\
Pekerjaan & & \\
$\quad$ Tidak Bekerja & 28 & 93,3 \\
$\quad$ Bekerja & 2 & 6,7 \\
Lama Menjadi Kader & & \\
$\quad$ < 2 Tahun & 10 & 33,3 \\
2 - 5 Tahun & 18 & 60,0 \\
$\quad$ > 5 Tahun & 2 & 6,7 \\
\hline Jumlah & 30 & 100,0 \\
\hline
\end{tabular}

\section{Perbandingan Nilai Pengetahuan Sebelum dan Sesudah Penyuluhan}

Perbandingan nilai pengetahuan kader posyandu sebelum dan sesudah dilakakukan penyuluhan kesehatan tentang penyakit pneumonia pada balita dapat dilihat pada tabel 2 berikut ini.

Tabel 2. Perbandingan nilai pengetahuan sebelum dan sesudah penyuluhan

\begin{tabular}{lcc}
\hline Waktu & $\begin{array}{c}\text { Jumlah } \\
\text { Nilai }\end{array}$ & Std. Deviasi \\
\hline Sebelum & 27,17 & 2,805 \\
Sesudah & 29,00 & 1,365 \\
\hline
\end{tabular}

Berdasarkan hasil penelitian (tabel 2) diatas dapat diketahui bahwa nilai pengetahuan responden setelah dilakukan penyuluhan kesehatan ternyata menunjukan nilai lebih tinggi dari pada nilai sebelum penyuluhan kesehatan. Kemudian standar deviasi nilai pengetahuan setelah penyuluhan kesehatan lebih kecil dari nilai standar deviasi sebelum penyuluhan kesehatan. 
Kemudian untuk melihat apakah perubahan nilai pengetahuan sebelum dan sesudah bermakna benar-benar secara statistik maka dari uji stastitik paired t-tes tingkat kemaknaan $(\alpha)$ 0,05 (5\%), didapatkan bahwa pada nilai t hitung $=-3.278$ dengan Sig. $=0,003$ $(<0,05)$, artinya penyuluhan kesehatan dalam meningkatkan pengetahuan kader posyandu tentang pencegahan penyakit pneumonia pada balita di wilayah kerja Puskesmas Darul Kamal Tahun 2017 efektif.

Hasil penelitian ini menemukan bahwa penyuluhan kesehatan tentang pencegahan pneumonia pada balita yang diberikan kepada kader kesehatan efektivitas dalam meningkatkan pengetahuan kader. Penyuluhan kesehatan adalah gabungan berbagai kegiatan dan kesempatan yang berlandaskan prinsip-prinsip belajar untuk mencapai suatu keadaan, dimana individu, keluarga, kelompok atau masyarakat secara keseluruhan ingin hidup sehat, tahu bagaimana caranya dan melakukan apa yang bisa dilakukan, secara perseorangan maupun secara kelompok dengan meminta pertolongan ${ }^{13}$. Banyak faktor yang mempengaruhi keberhasilan pelaksanaan penyuluhan kesehatan. Effendy dan Uchjana Onong ${ }^{13}$, mengemukakan keberhasilan suatu penyuluhan kesehatan dipengaruhi oleh faktor penyuluh, sasaran dan proses penyuluhan. Ia menjelaskan faktor penyuluh, misalnya kurang persiapan, kurang menguasai materi yang akan dijelaskan, penampilan kurang meyakinkan sasaran, bahasa yang digunakan kurang dapat dimengerti oleh sasaran, suara terlalu kecil dan kurang dapat didengar serta penyampaian materi penyuluhan terlalu monoton sehingga membosankan. Faktor sasaran, misalnya tingkat pendidikan terlalu rendah sehingga sulit menerima pesan yang disampaikan, tingkat sosial ekonomi terlalu rendah sehingga tidak begitu memperhatikan pesan-pesan yang disampaikan karena lebih memikirkan kebutuhan yang lebih mendesak, kepercayaan dan adat kebiasaan yang telah tertanam sehingga sulit untuk mengubahnya, kondisi lingkungan tempat tinggal sasaran yang tidak mungkin terjadi perubahan perilaku. Faktor yang ketiga adalah proses penyuluhan, misalnya waktu penyuluhan tidak sesuai dengan waktu yang diinginkan sasaran, tempat penyuluhan dekat dengan keramaian sehingga menggangu proses penyuluhan yang dilakukan, jumlah sasaran penyuluhan yang terlalu banyak, alat peraga yang kurang, metoda yang digunakan kurang tepat sehingga membosankan sasaran serta bahasa yang digunakan kurang dimengerti oleh sasaran. Kemudian Tim Ensor and Cooper ( 2004) ${ }^{14}$ mengemukakan bahwa faktor utama dan sangat penting yang mempengaruhi efektivitas penyuluhan kesehatan adalah tingkat pendidikan dari sasaran penyuluhan. ${ }^{14}$ Sehubungan dengan hal tersebut Notoadmodjo (2011) mengemukakan sejumlah faktor yang mempengaruhi seseorang dalam menerima pesan kesehatan yaitu pendidikan, pengalaman atau masa kerja, usia dan informasi. ${ }^{15}$ Lebih lanjut hasil penelitian lain menunjukan bahwa, dalam meningkatkan pengetahuan menjadi lebih signifikan apabila didukung alat peraga khususnya modul dan perlu dilakukan follow-up terhadap intervensi yang dilakukan sehingga pengetahuan benar merupakan hasil dari proses intervensi. Dampak akhir adalah perubahan kondisi status kesehatan balita menjadi labih baik. ${ }^{16,17}$ Bila dibandingkan teori-teori tersebut maka penelitian ini telah mengidentifikasi beberapa faktor yang mendukung keberhasilan penyuluhan kesehatan tersebut. Dari segi penyuluh kegiatan penyuluhan dilakukan oleh dokter puskesmas yang sudah berpengalaman dan tidak asing dimata para kader, karena sudah terbiasa memberikan pengarahan dan penyuluhan kepada mereka sehingga lebih meningkatkan kepercayaan para kader terhadap penyuluh tersebut. Dari sisi sasaran, penelitian ini mengidentifikasi bahwa sebagian besar pendidikan dari kader posyandu yaitu tingkat pendidikan menengah 53,4\%. Artinya efektifnya penyuluhan kesehatan terhadap kader kesehatan tidak terlepas dari kemampuan dari kader menerima materi penyuluhan. Dari sisi kepercayaan dan lingkungan kader kesehatan orang yang sudah terbiasa dengan lingkumgan kesehatan karena mereka sudah terlatih untuk menjadi pelopor kesehatan di desanya sehingga tidak asing dengan suasana atau lingkungan kesehatan. Hal ini juga didukung oleh sebagian besar kader posyandu telah menjadi kader antara 2-5 tahun yaitu 60\%. Kemudian dari segi pekerjaan walaupun sebagian besar kader tidak 
bekerja $(93,3 \%)$, namun pada dasarnya sesuai dengan kebiasaan orang yang tinggal di pedesaan kader-kader tersebut memiliki pekerjaan informal sebagai ibu rumah tangga dan istri dalam membantu pekerjaan suaminya, sehingga faktor social ekonomi tidak menjadi permasalahan yang akan menghambat proses penerimaan materi penyuluhan. Kemudian faktor penyuluh atau orang yang memberikan penyuluha kesehatan, dalam kegiatan ini materi penyuluhan kesehatan diberikan langsung oleh dokter puskesmas yang sudah berpengalaman dan terbiasa memberikan penyuluhan kesehatan kepada kader sehingga sangat menguasai materi penyuluhan dan mengetahui sasaran dari kegiatan penyuluhan. Alat peraga yang digunakan dalam kegiatan ini computer dan proyektor sehingga materi penyuluhan dapat disampaikan secara audiovisual dengan penekanan materi penyuluhan dan pemutaran film atau vedio tentang penyakit pneumonia pada balita. Hal ini dapat dilihat dari selisih nilai tes sebelum penyuluhan yaitu 27,17 dan nilai setelah penyuluhan sebesar 29,00 memiliki selisih yang tidak terlalu besar, yaitu 1,83 artinya jauh sebelum penyuluhan dilaksanakan para kader posyandu sudah mengetahui sedikit banyaknya tentang penyakit pneumonia pada balita melalui media lain seperti televisi, surat kabar, atau poster, leaflet baik yang disebarkan oleh tenaga kesehatan ataupun yang ditempelkan pada papan informasi di Puskesmas. Sehingga penyuluhan kesehatan ini hanya media untuk mengulang kembali pengetahuan yang mereka miliki sebalumnya.

\section{KESIMPULAN}

Kegiatan Penyuluhan kesehatan efektif dalam meningkatkan pengetahuan kader posyandu tentang pencegahan penyakit pneumonia pada balita di wilayah kerja Puskesmas Darul Kamal Tahun 2017.

\section{DAFTAR PUSTAKA}

1. Vinogradova Y, Hippisley-Cox J, Coupland C. Identification of new risk factors for pneumonia: Population-based case-control study. British Journal of General Practice. 2009;59(567):742-749.

doi:10.3399/bjgp09X472629.

2. Campbell H, el Arifeen S, Hazir T, O'Kelly $\mathrm{J}$, et al. Measuring Coverage in $\mathrm{MNCH}$ : Challenges in Monitoring the Proportion of Young Children with Pneumonia Who Receive Antibiotic Treatment. PLoS Medicine. 2013;10(5):1-6. doi:10.1371/journal.pmed.1001421.

3. Kosai H, Tamaki R, Saito M, Tohma K, et al. Incidence and Risk Factors of Childhood Pneumonia-Like Episodes in Biliran Island, Philippines-A Community-Based Study. Plos One. 2015;10(5): 0125009. doi:10.1371/journal.pone.0125009.

4. Rudan I, Boschi-Pinto C, Biloglav Z, Mulholland K, Campbell H. Epidemiology and etiology of childhood pneumonia. Bulletin of the World Health Organization. 2008;86(5):408-416. doi:10.2471/BLT.07.048769.

5. Depkes RI. Pedoman Penyelenggaraan Imuniasasi. Jakarta; 2004.

6. Dinkes Prov. Aceh. Profil Kesehatan Aceh. Banda Aceh; 2014.

7. Puskesmas Darul Kamal. Profil Kesehatan Puskesmas. Aceh Besar; 2014.

8. Thorsson S, Holmer B, Andjelic A, Lindén J, Cimerman S, Barregard L. Carbon monoxide concentrations in outdoor woodfired kitchens in Ouagadougou, Burkina Faso - Implications for women's and children's health. Environmental Monitoring and Assessment. 2014;186(7):4479-4492. doi:10.1007/s10661-014-3712-y.

9. Gouveia N, Fletcher T. Respiratory diseases in children and outdoor air pollution in São Paulo, Brazil: a time series analysis. Occupational and environmental medicine. 2000;57(7):477-483. doi:10.1136/oem.57.7.477.

10. World Health Organization. Pneumonia. WHO.

11. Sidiq R, Sitio R, Hajar S, Polytechnic AH, et al. Factors Related to Incidence of Pneumonia among Toddlers. Kesmas UI. 2016;11(2):63-67. doi:10.21109/kesmas.V11i2.1044. 
12. Dirjen PPPL Kemenkes RI. Pedoman Pengendalian Infeksi pernafasan akut. In: Jakarta; 2011.

13. Effendy, Uchjana Onong. Ilmu Komunikasi Teori Dan Praktek. Bandung: Penerbit PT. Remaja Rosda Karya.; 2003.

14. Tim Ensor, Cooper S. Overcoming barriers to health service access: Influencing the demand side. In: Health Policy and Planning. Vol 19. ; 2004:69-79. doi:10.1093/heapol/czh009.

15. Notoadmodjo S. Promosi Kesehatan Dan Ilmu Perilaku. Jakarta: Rineka Cipta; 2011.

16. Rahmad AL, Hendra A, Miko A. Peningkatan Pengetahuan Calon Pengantin melalui Konseling ASI Eksklusif di Aceh Besar. Indonesian Bulletin of Health Research. 45(4):249-256.

17. AL Rahmad AH, Miko A, Hadi A. Kajian Kejadian Pendek pada Anak Balita Ditinjau dari Pemberian ASI Eksklusif, MP-ASI, Status Imunisasi dan Karakteristik Keluarga di Kota Banda Aceh. Jurnal Kesehatan Ilmiah Nasuwakes. 2013;6(2):169-184. 